\title{
A Promising Vegetable Pigeonpea (Cajanus cajan L.) Variety Released for Ilocos Region, Philippines
}

Jocelyn A. Bernabe ${ }^{1 *}$

${ }^{1}$ Mariano Marcos State University,College of Agriculture, Food \& Sustainable Development, Dingras Campus, Barangay Madamba, Dingras, Ilocos Norte 2913 Philippines

Article History
Received: 27.02 .2021
Accepted: 06.04 .2021
Published: 16.04 .2021
Journal homepage:
http://www.easpublisher.com
Quick Response Code

Abstract: The National Seed Industry Council (NSIC) had released a new variety of pigeonpea or kadios (Cajanus cajan L.), one of the climate resilient crops ideal for the Ilocos Region in the Philippines and have similar performance to other regions of the country. A variety adaptable to year-round production under all soil conditions including marginal areas specially in Regions 1, 2, and 3 pigeonpea growing areas. ICP 7035 (MMSU-ICRIP MJ) was derived following selection method from the germplasm collection at ICRISAT, Hyderabad, India. It was brought later to the Philippines with legitimate supporting documents as Material Transfer Agreement (MTA) and others. This variety has non-determinate growth habit. The purity was maintained through selections made by researchers at MMSU. Series of trials in accordance with the regulations of the NSIC were done. Yield is far superior than the local varieties being used. It has an average seed yield of 1.282 to as high as 2.0 tons per hectare as compared to the local check with .516 tons per hectare. It has yellow-red colored flowers. It flowers and matures earlier with 96 and 142 days respectively as compared to 130 and 201 days respectively of the local check. The seeds are sweet in taste due to high sugar content. It is suitable to market it as immature pods for vegetable purpose. It was found resistant to diseases like Sterility mosaic, Cercospora leaf spot, rust and other pests identified in legumes.

Keywords: Pigeonpea, Germplasm Collection, Selection, Non-determinate, MTA, Sterility Mosaic, Cercospora Leaf Spot, Rust.

Copyright ( 12021 The Author(s): This is an open-access article distributed under the terms of the Creative Commons Attribution 4.0 International License (CC BY-NC 4.0) which permits unrestricted use, distribution, and reproduction in any medium for non-commercial use provided the original author and source are credited.

\section{INTRODUCTION}

Agriculture is the basic source of livelihood in the countryside. Rice and corn are the leading commodities in Ilocos and Cagayan Valley regions, and vegetables as well as rootcrops in the Cordillera region.

Ilocos Norte has a population of more than 0.5 $M$ that is dependent on intensive farming such as tobacco, garlic, onion, tomato, and rainfed rice. However, for the last five years, the production of these crops has been declining due to drought and flooding, apparently attributed to climate change.

The province of Isabela is the largest province in Cagayan Valley with a population of $1.2 \mathrm{M}$. About $51 \%$ of the population engaged in agriculture has been contributing two thirds of the country's rice and corn production in 2001. However, the production of these crops has tremendously declined due to recurrent drought and flooding. From 2005-2007, the entire region experienced extreme drought and flooding resulting in very poor harvests. Practically no rain was received during the months of May to September, which are normally the rainy months. Rainfed upland farming is thus vulnerable to seasonal climate change. Damage to agriculture attributed to drought and flooding was estimated to be approximately Php $870 \mathrm{M}$ in 2005 (DA-RFU, Isabela, 2008).

In the Cordillera region, the land area is approximately $98 \%$ dryland, where $80 \%$ of the population relies on upland farming as major source of farm income. Dryland crops such as cassava, taro, sweet potato and vegetables are usually planted to boost livelihood activities of poor upland farmers. Agriculture in the highlands is likewise threatened not only by drought but also by flash floods.

On the other hand, the introduction of pigeonpea providing multi-functions such as food, feeds, fertilizer and fuel wood source finds a valuable place in the farming system of smallholder farmers. Known for its deep rooting characteristics and ability to grow under harsh environments, pigeonpea is regarded as a good alternative legume crop in the uplands as well 
as in the rainfed lowland to help ensure food and nutritional security.

Pigeonpea is a versatile crop that is very much ideal and a potential cash crop especially in areas where rice and corn are grown because of its uses that it can be eaten as vegetable (green pods) due to its high protein content $(20-22 \%)$ in lieu of animal products or in association with meat. Pigeonpea can likewise be used as feed for livestock and poultry. The green fodder can be utilized as a good protein source in animal diets and the seeds can be substituted as feeds for poultry and swine production. Aside from providing food for human and feeds for animals, pigeonpea production can support the livelihood economy of small farm families. Because of its nutritional value and numerous uses as food and feed will help alleviate the socio-economic condition in these areas.

Pigeonpea is a potential rotational crop with rice. It has shown good promise in terms of its ability to suppress weeds, reduce nematodes [1] and maintain rice yields. It also has economic potential, although this has so far been limited by the market. However, where there is market potential farmers have shown strong interest. In rice, it maintains nutrient replenishment and reducing nematode pressure.

Pigeonpea is a perennial crop, but is most often cultivated as an annual. Traditional landraces and cultivars are harvested after 180-280 days, though the plants may be left in the field to re-grow and provide feed for animals. In rainfed situations, pigeonpea provides more stability of productivity over environments and seasons than the cereals with which it is intercropped.

In the Philippines, pigeonpea is grown as a backyard crop, along the roads, in field bunds, as hedges in irrigation canals and serves as fence surrounding a field to protect the growing crops from stray animals. It is primarily grown for its tender green pods with soft seeds and cooked as vegetables like cowpea and beans.

Moreover, this could be a rotation or alternative crop for rice, corn and even vegetables. Thus, an important crop for subsistence agriculture due to its drought tolerance, ability to recover from losses caused by various stresses, its high protein content (20$22 \%$ ), grain (seed) quality for food, feed, and fodder and even for fuel wood. Its ability to enrich soils further adds to the value of among smallholding farmers in the country.

Thus this project aimed to evaluate and identify pigeonpea adaptable varieties/lines that will be acceptable to the farmers for eventual promotion and adoption that provides significant niche in the food economy of households, most especially in the hilly/upland areas where there is minimal rainfall and marginal infertile soil in Ilocos, Cordillera areas and Cagayan valley.

Researches on varietal trials were conducted at the Isabela State University (ISU-Cabagan and Echague campuses), Nueva Vizcaya State University (NVSU), Benguet State University and Mariano Marcos State University (MMSU). Likewise, production areas were established under the supervision of Department of Agriculture (DA) and Department of Agrarian ReformAgrarian Reform Communities (DAR-ARC). Further, consultations, lectures and training on the targeted pilot areas where the commercial production and utilization of pigeonpea were conducted. Techno demos were also conducted on farmers' field to showcase the growing of pigeonpea and its uses to alleviate and solve poverty problems in the countryside.

In the Philippines, pigeonpea can be marketed in different market outlets especially in Regions I (Ilocos Norte, Ilocos Sur), Cordillera Administrative Region, Cagayan Valley and even in other regions of Luzon, Visayas and Mindanao. Likewise, pigeonpea seeds are now being sold at universities like the Benguet State University, Pampanga State University, University of Southern Mindanao, Central Mindanao State University and Bicol State University of Agriculture which are processing legumes seeds for their income generating projects and feeding programs, respectively.

\section{REVIEW OF LITERATURE}

Because of its unique characteristics, pigeonpea is recognized as an important crop for subsistence agriculture due to its drought tolerance characteristics, and ability to recover from the losses caused by various stresses. Its pods for food, whether consumed as green peas or dry grains, consist of 20 percent to as high as 32 percent protein, which play a vital role in meeting the protein needs of the vegetarian population [2]. The leaves and dry pods as forage and fodder, the woody stems are valuable as shelter, fuel wood, thatch and fencing and the plants are also used to culture the lac-producing insect. Good quality pigeonpeas are for human consumption whiles the cracked and pinched grains and by products may be available for incorporation into animal feeds [3].

In the Philippines, pigeonpea is grown and often used as lining fence around small fence, on field bunds, on road sides and hilly slopes. Farmers in North Luzon often grew pigeonpea on vacant areas/fields to fill the gap and in marginal areas where they have 
problems in growing other crops. Pigeonpea is grown in backyard, its perennial habit enables the production of multiple harvests that can be intercropped with other crops especially the short stature and the maturity is short.

Pigeonpea is known to produce more nitrogen per unit of plant biomass than most other legumes and can nodulate in most soils although it produces fewer nodules than any other legumes [4]. It is considered to be tolerant to low and high temperatures. Aside from being a nitrogen fixing plant, pigeonpea roots go as deep as 2-5 meters thereby use water and micronutrients up in the organic system to meet its needs. The deep root system allows for optimum moisture and nutrient utilization. Its root system has the ability to break the plough pans, thus improving soil structure. The leaves are important sources of organic matter and nitrogen adding as much as $40 \mathrm{~kg}$ per hectare to the soil [5]. Its ability to enrich soils further adds to the value of the crop, thus it finds an important place in farming systems adopted by small-farm holders in developing countries [6].

Pigeonpea can adapt to a wide range of soil types from gravely stones to heavy clay loams of close texture and high moisture content provided there is no standing water on the soil surface or excessive soil salinity. It will grow in infertile soils, on acidic sands and alkali clays. Extensive ground cover of pigeonpea prevents soil erosion, serves as windbreak hedge, encourages filtration, minimize sedimentation and smother weeds.

Under MMSU Ilocos Norte condition, promising ICRISAT pigeonpea varieties can produce yields ranging from 1.0 ton to 2.74 tons per hectare. Under farmers' field condition, a yield of more than $1000 \mathrm{~kg}$ per hectare was produced in 1988 [7]. On the other hand, under open market, a kilo of pigeonpea matured green pods cost Php30-35 or when marketed as green seeds (separated from the pod) it cost Php35-40 per one half kilo. Dry seeds costs Php75-85 per kilo.

\section{Methodology}

Qualitative and quantitative characteristics evaluation of ICRISAT pigeonpea lines under specific cropping system were undertaken across locations in Northern Luzon.

Based on the protocol, promising 9 entries from ICRISAT Pigeonpea lines namely: ICPL 88039 and ICPL 87091 classified as short duration maturity types: ICPL 20092, ICPL 87119 and ICP 7035 under medium duration: and four cultivars bred from eastern Africa (ICEAP) mostly longer duration genotypes includes the ICEAP 00932; ICEAP 00040; ICEAP 00554; and ICEAP 00557 were used as entries for onstation evaluation trials and finally on farm trials.

These pigeonpea lines were subjected to yield parameter evaluation as relay to vegetables in BSU; intercrop to corn at ISU; planted after rice at MMSU, and as conservation and forage crops at DA-CVHROS and ISU, respectively, first for one cropping year (20122013). Out of the 9 lines used, the researchers selected the best 4 promising lines in all locations, farther tested and maintained for three cropping years (2013-2015). These are: ICPL 87091, ICP 7035, ICEAP 00554, ICEAP 00557. These selected lines were grown together with and compared with the performance of the farmer's variety "Burik" which was then used as the local check.

Randomized complete block design with 4 replications was used in all the locations following the recommended technology protocol of the National Seed Industry Council as established by the pigeonpea researchers. Complete fertilizer was applied at the rate of $10-10-10$ to $30-30-30 \mathrm{kgNPK}^{\text {-ha }}$ depending on the soil conditions in the growing areas. Planting distance of $60 \times 50 \mathrm{~cm}$ during dry season and $75 \times 50 \mathrm{~cm}$ during wet season was used.

Based on results, the identified lines with the highest yield as well as the most resistant to some diseases identified in legumes was recommended for varietal release to the Bureau of Plant IndustryNational Seed Industry Council which was later approved and released as a variety for the Ilocos, Cordillera areas and Cagayan valley.

\section{RESUlTS AND DisCuSSIONS}

Results on the yield performance of the different locations are summarized in tables 1, 2 and 3 by cropping year (October 2012 to March 2015).

Observations show that in all the three cropping years and in all locations, generally, ICP 7035 significantly gave the highest yield. Table 1 shows that this line had the highest yield in all locations as MMSU, Isabela, Nueva Vizcaya and Benguet areas with1,510; 695.4; 2,290; 155.9; and 720 kilos per hectare respectively, as compared to the Local check, "Burik" with yields of $860 ; 225 ; 456 ; 105 ; 210$ kilos per hectare respectively. 
Table-1: Summary of the seed yield $\left(\mathrm{kg}^{\text {-ha }}\right)$ of pigeonpea lines. October 2012-Mar. 2013

\begin{tabular}{|l|c|c|c|c|c|c|}
\hline \multicolumn{1}{|c|}{ ENTRY } & $\begin{array}{c}\text { MMSU- } \\
\text { ILOCOS } \\
\text { NORTE }\end{array}$ & $\begin{array}{c}\text { ISU- } \\
\text { ISABELA }\end{array}$ & $\begin{array}{c}\text { DA-VES- } \\
\text { NUEVA } \\
\text { VIZCAYA }\end{array}$ & $\begin{array}{c}\text { BSU - } \\
\text { BENGUET }\end{array}$ & $\begin{array}{c}\text { FARMER'S } \\
\text { FIELD }\end{array}$ & MEAN \\
\hline ICP 00554 & $1,190.0^{\mathrm{c}}$ & $509.4^{\mathrm{b}}$ & $550.0^{\mathrm{c}}$ & 130.0 & $250.0^{\mathrm{d}}$ & 525.9 \\
\hline ICP 00557 & $1,310.0^{\mathrm{b}}$ & $536.2^{\mathrm{b}}$ & $1,080.0^{\mathrm{b}}$ & 126.0 & $610.0^{\mathrm{b}}$ & 732.4 \\
\hline ICPL 87091 & $600.0^{\mathrm{e}}$ & $299.2^{\mathrm{c}}$ & $570.0^{\mathrm{c}}$ & 137.0 & $320.0^{\mathrm{c}}$ & 385.24 \\
\hline ICP 7035 & $1,510.0^{\mathrm{a}}$ & $695.4^{\mathrm{a}}$ & $2,290.0^{\mathrm{a}}$ & 155.9 & $720.0^{\mathrm{a}}$ & $1,074.26$ \\
\hline Local (burik) & $860.0^{\mathrm{d}}$ & $225.0^{\mathrm{c}}$ & $456.0^{\mathrm{d}}$ & 105.0 & $210.0^{\mathrm{d}}$ & 371.2 \\
\hline G MEAN & $1,094.0$ & 453.04 & 989.2 & 130.8 & 422.0 & 617.8 \\
\hline CV (\%) & 5.2 & 6.0 & 5.0 & 4.8 & 7.1 & \\
\hline LSD (0.05) & 0.001 & 0.018 & 0.001 & & 0.001 & \\
\hline
\end{tabular}

During the second cropping year (2013-2014), Table 2, it again showed the same results wherein ICP 7035 had significantly the highest yield as compared to other lines used with 2,$500 ; 1,300 ; 2,100 ; 728$; and 821 kilograms per hectare respectively specially the check variety with 1,$200 ; 250 ; 620 ; 580$ and 658 kilograms per hectare respectively. for MMSU, Isabela, Nueva Vizcaya and Benguet areas.

Table-2: Summary of the seed yield $\left(\mathrm{kg}^{\text {-ha }}\right)$ of pigeonpea lines. October 2013-March 2014

\begin{tabular}{|l|c|c|c|c|c|c|}
\hline \multicolumn{1}{|c|}{ ENTRY } & $\begin{array}{c}\text { MMSU- } \\
\text { ILOCOS } \\
\text { NORTE }\end{array}$ & $\begin{array}{c}\text { ISU- } \\
\text { ISABELA }\end{array}$ & $\begin{array}{c}\text { DA-VES- } \\
\text { NUEVA } \\
\text { VIZCAYA }\end{array}$ & $\begin{array}{c}\text { BSU - } \\
\text { BENGUET }\end{array}$ & $\begin{array}{c}\text { FARMER'S } \\
\text { FIELD }\end{array}$ & MEAN \\
\hline ICP 00554 & $2,000.0^{\mathrm{b}}$ & $1,200.0^{\mathrm{b}}$ & $1,100.0^{\mathrm{b}}$ & $520.0^{\mathrm{b}}$ & $485.0^{\mathrm{e}}$ & $1,061.0$ \\
\hline ICP 00557 & $1,460.0^{\mathrm{d}}$ & $810.0^{\mathrm{d}}$ & $1,000.0^{\mathrm{c}}$ & $485.0^{\mathrm{c}}$ & $560.0^{\mathrm{d}}$ & 863.0 \\
\hline ICPL 87091 & $1,890.0^{\mathrm{c}}$ & $1,100.0^{\mathrm{c}}$ & $960.0^{\mathrm{d}}$ & $436.0^{\mathrm{c}}$ & $720.0^{\mathrm{b}}$ & $1,021.2$ \\
\hline ICP 7035 & $2,500.0^{\mathrm{a}}$ & $1,300.0^{\mathrm{a}}$ & $2,100.0^{\mathrm{a}}$ & $728.0^{\mathrm{a}}$ & $821.0^{\mathrm{a}}$ & $1,489.8$ \\
\hline Local (burik) & $1,200.0^{\mathrm{e}}$ & $250.0^{\mathrm{e}}$ & $620.0^{\mathrm{e}}$ & $580.0^{\mathrm{b}}$ & $658.0^{\mathrm{c}}$ & 661.6 \\
\hline G MEAN & $1,810.00$ & 932.0 & $1,156.0$ & 549.8 & 648.8 & $1,019.3$ \\
\hline CV (\%) & 3.6 & 7.0 & 5.0 & 7.3 & 6.5 & \\
\hline LSD $(0.05)$ & 0.001 & 0.001 & 0.001 & 0.018 & 0.001 & \\
\hline
\end{tabular}

Table 3 shows yields of ICP 7035 as the highest and local check having the lowest yield with 2,$005 ; 997.7 ; 2,195 ; 441.9$; and 770.5 kilograms per hectare as against the local check with as compared to the local check which is significantly the lowest in all areas with 1,$030 ; 237.5 ; 538 ; 342.5$ and 434 kilograms per hectare respectively.

Higher yields were obtained in second cropping year (2013-2014) than the first (2012-2013) and last cropping (2014-2015) years in all locations.

Table-3: Summary of the seed yield $\left(\mathrm{kg}^{\text {-ha }}\right)$ of pigeonpea lines. October 2014-March 2015

\begin{tabular}{|l|l|l|l|l|l|l|}
\hline ENTRY & $\begin{array}{l}\text { MMSU- } \\
\text { ILOCOS } \\
\text { NORTE }\end{array}$ & $\begin{array}{l}\text { ISU- } \\
\text { ISABELA }\end{array}$ & $\begin{array}{l}\text { DA-VES- } \\
\text { NUEVA } \\
\text { VIZCAYA }\end{array}$ & $\begin{array}{l}\text { BSU - } \\
\text { BENGUET }\end{array}$ & $\begin{array}{l}\text { FARMER'S } \\
\text { FIELD }\end{array}$ & MEAN \\
\hline ICP 00554 & $1,590.0^{\mathrm{b}}$ & $854.7^{\mathrm{b}}$ & $825.0^{\mathrm{c}}$ & $325.0^{\mathrm{b}}$ & $367.5^{\mathrm{d}}$ & 792.4 \\
\hline ICP 00557 & $1,385.0^{\mathrm{c}}$ & $673.1^{\mathrm{c}}$ & $1,040.0^{\mathrm{b}}$ & $305.5^{\mathrm{c}}$ & $585.0^{\mathrm{b}}$ & 797.7 \\
\hline ICPL 87091 & $1,245.0^{\mathrm{d}}$ & $699.6^{\mathrm{c}}$ & $765.0^{\mathrm{d}}$ & $286.5^{\mathrm{d}}$ & $520.0^{\mathrm{b}}$ & 703.2 \\
\hline ICP 7035 & $2,005.0^{\mathrm{a}}$ & $997.7^{\mathrm{a}}$ & $2,195.0^{\mathrm{a}}$ & $441.9^{\mathrm{a}}$ & $770.5^{\mathrm{a}}$ & $1,282.0$ \\
\hline Local (burik) & $1,030.0^{\mathrm{e}}$ & $237.5^{\mathrm{d}}$ & $538.0^{\mathrm{a}}$ & $342.5^{\mathrm{b}}$ & $434.0^{\mathrm{c}}$ & 516.4 \\
\hline G MEAN & $1,451.0$ & 692.52 & $1,072.60$ & 340.28 & 535.4 & 818.3 \\
\hline CV $(\%)$ & 6.0 & 5.3 & 5.1 & 3.7 & 7.7 & \\
\hline LSD $(0.05)$ & 0.001 & 0.018 & 0.001 & 0.014 & 0.018 & \\
\hline
\end{tabular}

\section{SuMMARY AND CONCLUSION}

The project on evaluation trials for ICRISAT Pigeonpea genotypes subsumed under Accelerating adoption, production and utilization program for pigeonpea genotypes is a research initiative spearheaded by PCAARRD in collaboration with ICRISAT participated in by four SUC's (Mariano Marcos State University, Isabela State UniversityCabagan campus, Benguet State University, Nueva 
Vizcaya State University and DA line agencies in Northern and Central Philippines such as the Department of Agriculture-Vizcaya Experimental Station (Nueva Vizcaya) and other DA line agencies in the regions 1,2 , and 3 . The project aimed to evaluate and identify pigeonpea adaptable varieties/lines that will be acceptable to the farmers for eventual promotion and adoption that provides significant niche in the food economy of households, most especially in the hilly/upland areas where there is minimal rainfall and marginal infertile soil in Ilocos, Cordillera areas and Cagayan valley.
Based from the varietal trials conducted for three consecutive cropping years following the guidelines of the National Seed Industry Council under its National Cooperative Trials, ICP 7035 was found promising and acceptable and is now adopted by farmers in the mentioned locations to be grown with promising yield.

Below is the summary table on the characteristics of ICP 7035 which was observed through the growing seasons and as basis for recommendation of the line for variety approval and release.

Table-4: Varietal Characteristics of ICP 7035

\begin{tabular}{|l|c|c|}
\hline \multicolumn{1}{|c|}{ Characters } & $\begin{array}{c}\text { Variety Recommended } \\
\text { (ICP 7035) }\end{array}$ & $\begin{array}{c}\text { Check Variety } \\
\text { (Local Check) "Burik" }\end{array}$ \\
\hline a. Seed Yield (kg/ha) & $1,282.02$ & 516.4 \\
\hline b. Pod Yield (kg) & $2,862.9$ & 667 \\
\hline c. 100 seed weight (g) & 22.33 & 8.14 \\
\hline d. Plant height (m) & 1.27 & 1.99 \\
\hline e. Number of pods/plant & 145 & 82 \\
\hline f. Number of seeds/pod & 5.54 & 3.41 \\
\hline g. Days to flower & 96.86 & 130.25 \\
\hline h. Days to mature & 142.49 & 200.88 \\
\hline i. Cercospora Leaf spot & 1 & 2 \\
\hline j. Rust & 1 & Black speckled \\
\hline k. Color (at maturity) & Reddish brown & 5.54 \\
\hline l. Acceptability* & 7.03 & $\mathbf{5}$ \\
\hline
\end{tabular}

*RATING:9 - Like Extremely, 8-Like Very Much, 7 - Like, 6 - Like Moderately, 5 - Neither Like nor Dislike,

4 - Dislike Moderately, 3 -Dislike, 2 - Dislike Very Much, 1 - Dislike Extremely

\section{Copy of the application for varietal registration and release submitted to National Seed Industry Council:} NATIONAL SEED INDUSTRY COUNCIL

Crop:

Line Name:

Pigeonpea (Cajanus cajan L.)

Type:
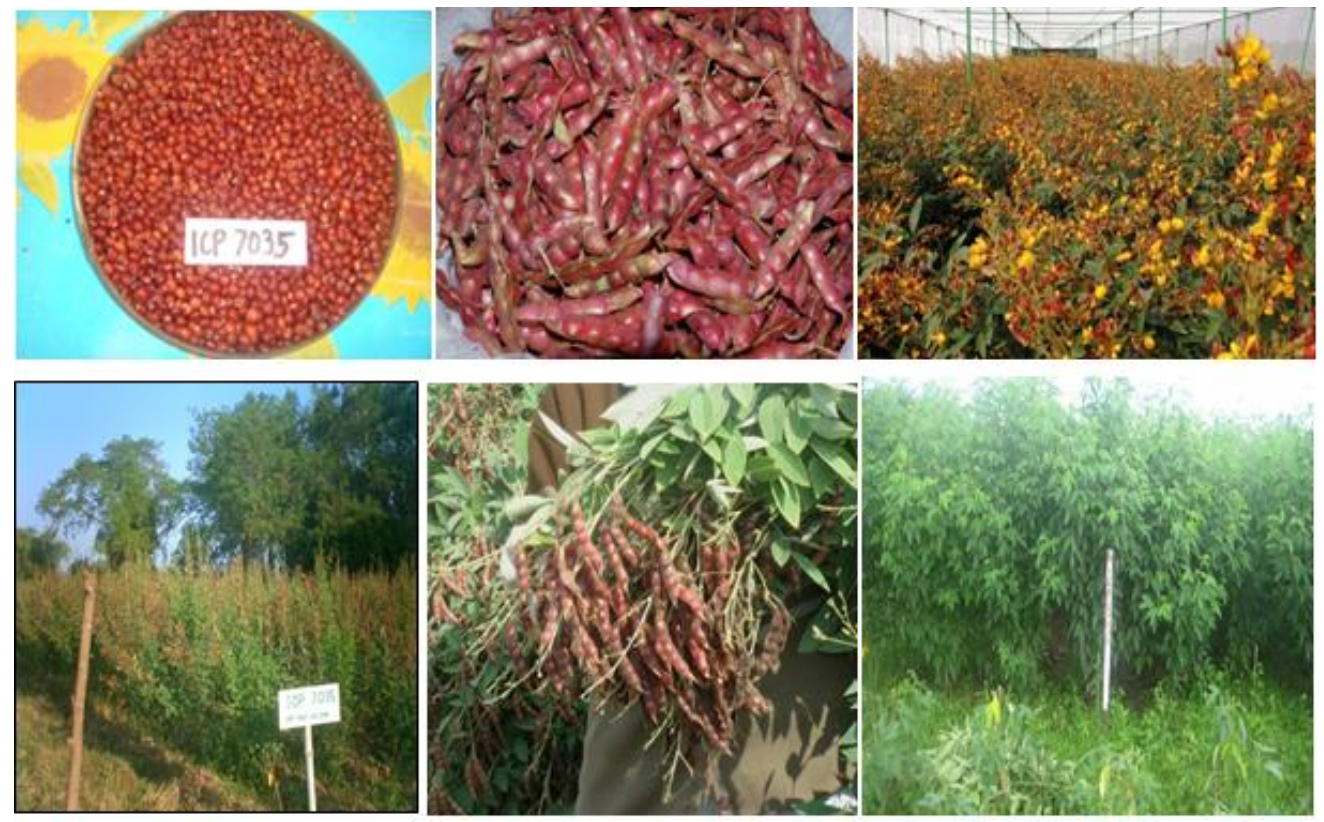
Background:

a) Sponsoring Agency:

Mariano Marcos State University (MMSU)

b) Breeding Institution: Purity maintenance (selection):

ICRISAT, India

c) Pedigree/Hybrid:

MMSU

d) Researchers Responsible for Sponsoring/Developing Variety:

- Jocelyn A. Bernabe

- Myer G. Mula

e) Seed availability:

Mariano Marcos State University

A copy of the Certificate of Registration by BPI-NSIC:

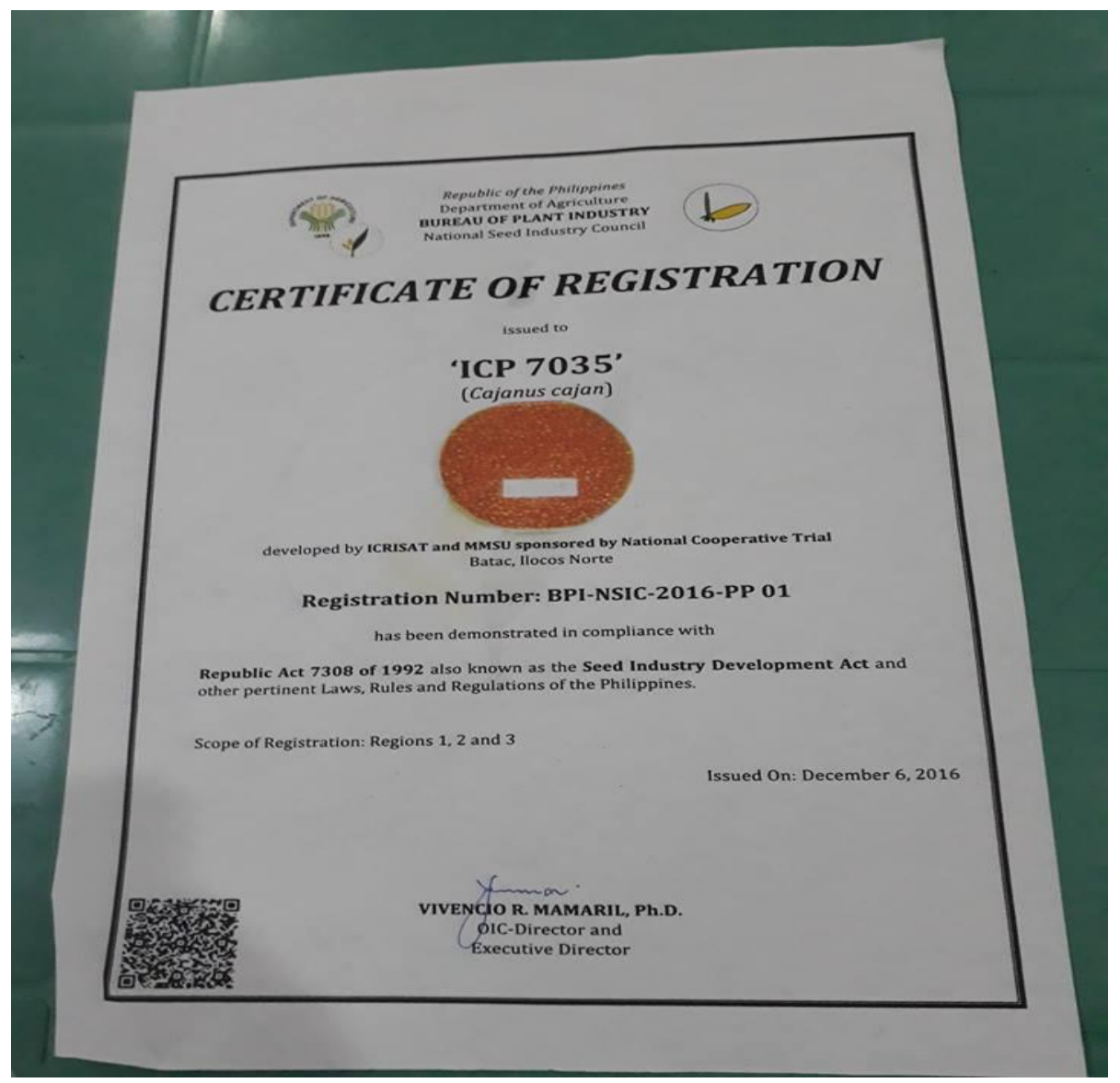

\section{ACKNOWLEDGEMENT}

The researchers would like to express their profound thanks to the following: the Mariano Marcos State University, especially the Research and Development Directorate for its support in the implementation of the project: the Philippine Council for Agriculture, Aquatic and Natural Resources Research and Development (PCAARRD) for funding the program where this paper was subsummed the International Crops Research Institute for the Semi-Arid Tropics (ICRISAT) in India headed by its former Director General Dr. William D. Dar who gave the seed materials used for the seed program; the members of the collaborating agencies: Isabela State University; Central Luzon State University, Benguet State University, Nueva Vizcaya State University with the Department of Agriculture-Vizcaya Experimental
Station for their valuable data inputs necessary in coming up with this paper. Above all, to the Almighty God for making all things possible for this work.

\section{REFERENCE}

1. Roder, W. (1998). Slash and burn rice systems in the hills of northern Lao PDR. Description, challenges, and opportunities. Los Baños, Philippines: International Rice Research Institute,

2. Singh, L., Gupta, S.C., \& Faris, D.G. (1990). Pigeonpea breeding. Pages 375-420 in The pigeonpea (Nene YL, Hall SD and Sheila VK, eds) Cambridge, UK: CAB International

3. Whiteman, P.C., \& Norton, B.W. (1981). Alternative uses for pigeonpea. Pages 365-376 in Proceedings of the International Workshop (1980) on pigeonpeas, Patancheru 502 324, Andhra 
Pradesh, India: International Crops Research Institute for the Semi-Arid Tropics.

4. Onim, J.F.M. (1987). Multiple uses of pigeonpea. Pages $115-120$ in Research on grain legumes in eastern and central Africa. Addra Ababa, Ethiopia. Intern'l Livestock Center for Africa (ILCA).

5. Kumar, R. (1981). Nitrogen fixation by pigeonpea. Pages 190-199 in Proceedings of the International
Workshop on Pigeonpea. ICRISAT, Patancheru 502 324, Andhra Pradesh, India. 15-19 December

6. Saxena, K.B. (2006). Page 76 in Seed production systems in pigeonpea. Patancheru 502 324, Andhra Pradesh, India: International Crops Research Institute for the Semi-Arid Tropics, 47.

7. Cudapas. (1988). Early pigeonpea adaptation yield trial in the Ilocos. Mariano Marcos State University, Batac, Ilocos Norte, Philippines.

Cite This Article: Jocelyn A. Bernabe (2021). A Promising Vegetable Pigeonpea (Cajanus cajan L.) Variety Released for Ilocos Region, Philippines. East African Scholars J Agri Life Sci, 4(4), 89-95. 